\title{
Social Interaction of Class IV Elementary School Students During the Covid-19 Pandemic
}

\section{Mayang Afriani1*, Zaka Hadikusuma Ramadan²}

\author{
1,2 Pendidikan Guru Sekolah Dasar, Universitas Islam Riau, Riau, Indonesia
}

\section{ARTICLE INFO}

\section{Article history:}

Received September 22, 202

Revised September 23, 2021

Accepted November 12, 202

Available online November 25, 2021

Kata Kunci:

Interaksi Sosial, Covid-19, Sekolah Dasar

Keywords:

Social Interaction, Covid-19, Elementary School

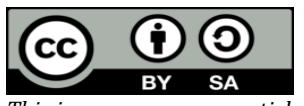

This is an open access article under the $\underline{C C}$ BY-SA license.

Copyright (C) 2021 by Author. Published by Universitas Pendidikan Ganesha.

\begin{abstract}
A B S T R A K
Dampak covid-19 dengan membatasi interaksi sosial juga dialami oleh pelajar. Namun interaksi sosial sangat dibutuhkan untuk seorang anak untuk bisa membangun karakter dan kemampuan sosialnya dalam berinteraksi dengan orang lain. Tujuan penelitian ini adalah menganalisis pola interaksi sosial di masa covid19 kelas IV sekolah dasar. Subyek penelitan yaitu 3 guru dan 90 siswa. Instrumen penelitian yaitu wawancara dan angket. Teknik pengumpulan data yang digunakan dalam penelitian ini adalah non tes, yaitu berupa kuesioner (angket), dan wawancara. Hasil penelitian menunjukkan bahwa interaksi sosial pada masa pandemi kurang efektif. Dibuktikan dari lima indikator, Bekerja sama nilai rata-rata 82,43\%, pada masa pandemi kurang efektif karena keterbatasan dan banyak hambatan-hambatan. keterbukaan nilai rata 82,43\% tergolong "baik", siswa masih banyak yang belum memahami teknologi untuk pembelajaran daring dan cara penggunaanya. Empati nilai rata-rata 80,95\% tergolong "baik", sudah ada kesadaran dalam diri siswa untuk berempati kepada temannya. Memberi motivasi nilai rata-rata 79,70\% tergolong "baik", Saat pembelajaran siswa satu sama lain saling memberi dukungan dan bekerja sama dalam mengerjakan tugas bersama dirumah. Rasa positif nilai rata-rata $81,56 \%$, siswa mampu mengembangkan nilainilai positifyang ada dilingkungan sekitar. Kesamaan dengan orang lain nilai ratarata $82,15 \%$, sudah ada sikap kesetaraan dalam diri siswa kepada temannya dalam bersama-sama mengerjakan tugas dan mengunpulkannya tugas. Dapat disimpulkan bahwa Interaksi Sosial siswa pada masa Covid-19 saat ini kurang berjalan dengan sempurna dibanding dengan tatap muka.
\end{abstract}

\begin{abstract}
A B S T R A C T
Students also experience the impact of Covid-19 by limiting social interaction. However, social interaction is needed for a child to build character and social skills in interacting with other people. This study aimed to analyze patterns of social interaction in the fourth grade COVID-19 period in elementary school. The research subjects were 3 teachers and 90 students. The research instruments are interviews and questionnaires. The data collection technique used in this study was non-test, namely a questionnaire (questionnaire) and interviews. The results showed that social interaction during the pandemic was less effective. As evidenced by the five indicators, working together has an average score of $82.43 \%$; during a pandemic, it is less effective due to limitations and many obstacles. The openness of the average value of $82.43 \%$ is classified as "good," and many students still do not understand technology for online learning and how to use it-empathy, with an average value of $80.95 \%$ (good). There is already an awareness in students to empathize with their friends. Giving motivation an average value of $79.70 \%$ is classified as "good" when learning students support each other and work together in doing assignments together at home. With a positive sense of the average value of $81.56 \%$, students can develop positive values in the surrounding environment. Similarity with others, the average value is $82.15 \%$, there is an attitude of equality in students to their friends in working on assignments and collecting assignments. It can be concluded that students' social interactions during the current Covid-19 period are not running perfectly compared to face-to-face.
\end{abstract}

\section{INTRODUCTION}

Humans are social creatures, will make relationships between individuals with other individuals, individuals with groups, and groups with groups. Social interaction is the main requirement for a person to carry out social activities. Social skills aim to gain reciprocity to establish relationships with other people. Social skills include communication, where students help each other in their environment (Damanik \& Setiawan, 2016; Handayani, 2017). Social interaction is also known as a social process that refers to a reciprocal relationship between two or more people, where everyone participates and plays an active role in interactive social life, namely actions or actions that are mutually beneficial (Anjasari et al., 2020; Herfinaly \& Aryani, 2013; Wakhid et al., 2019). Social interaction is the key to social life. In this process, 
dynamic social relations occur between individuals, individuals and groups, and groups. Social interaction is impossible if two conditions are not met: social contact and communication. Students can scold each other, exchange information, do homework, and chat. This type of activity is a form of social interaction (Hasti \& Nurfarhanah, 2013; Riansyah \& Wulandari, 2017). Social interaction in the family is a reciprocal relationship that occurs in mutual influence between individuals.

Students also experience the impact of Covid-19 by limiting social interaction. This policy makes teaching and learning activities in the face-to-face context temporarily suspended (Maulana \& Hamidi, 2020; Tamboto et al., 2021; Yulia, 2020). The government replaces learning with an online learning system through online learning applications (Dewi, 2020; Vera, 2020). Distance learning minimizes crowds as a natural step in implementing health protocols in the context of preventing the transmission of covid-19. Distance learning can be done anywhere between educators and students (Putri et al., 2021; Rahma \& Pujiastuti, 2021; Sari et al., 2021). Distance learning (PJJ) can use innovative learning to use engaging media to continue efficient learning (Firman \& Rahman, 2020; Prawiyogi et al., 2020). However, social interaction is needed because social interaction is the key to all social life. Without social interaction, there will be no life together. Especially for a child, social interaction is one thing that children need to build their character and social skills in interacting with other people (Xiao, 2018; Hasanah, 2019). On average, parents of students approve of online learning for a while to avoid covid-19. Parents also supervise children who study at home and help students who do the assignments given by the teacher. Currently, parents strongly agree that learning is done at home to avoid the spread of covid-19 (Astuti, 2021; Batubara \& Batubara, 2020; V. D. Putri, 2020).

Based on interviews with teachers at the Pekanbaru Elementary School, online learning was implemented at the beginning of the COVID-19 pandemic (in the network). In online learning, students' social interaction is limited, both in terms of working together, it is significantly hampered due to limitations. Currently, the only thing that can be done is between students near the house, the rest work with parents. Students' openness in interacting can only be done via google classroom, WhatsApp groups, and private chats between teachers and students. Students' empathy during the current pandemic has not been carried out properly due to social distancing. At this time, the teacher can only motivate students to do learning via mobile phones even though it is not the students who play the cellphone. Most of the parents answer the greeting from the teacher. Not all students have android phones, so students do not follow the lesson. Some parents are busy working, so their children are not taken care of to study during the pandemic. In the absence of parental attention during the pandemic, it is difficult for students and teachers to interact with each other. The school principal has provided an internet quota, but it is not enough. So, during the current pandemic, schools are opening a learning system, and the government has approved it, namely by two face-to-face meetings using two shifts, with only one student sitting at one desk and following health protocols by wearing a mask. The benefits of face-to-face are so that students can participate in learning and teachers can see social interactions can run smoothly even though the limited time given by the teacher at least communicates between students and teachers going well.

E-learning-based learning is a new thing and is currently a mandatory learning activity. The function of e-learning is to keep students safe from the threat of COVID-19 (Ali, 2020; Dewantara \& Nurgiansah, 2020; Maulana, 2021). In addition, E-learning can be used easily (Muhdi \& Nurkholis, 2021; Pratama \& Mulyati, 2020; I. P. Sari, 2017). Teachers must be innovative so that the indicators can carry out learning well. Teachers can use classroom, Edmodo, google meet, and zoom. in implementing learning (Mayer \& Wittrock, 2006; Sabran \& Sabara, 2019). Using E-learning can make students express their thoughts without directly seeing the teacher. E-learning is very easy to use regardless of the time of use. If students do not understand the learning material, then students can repeat the material until students understand (Ridha et al., 2021; Munastiwi, 2021). The results of previous research searches obtained several problems related to the process of social interaction during the covid-19 virus pandemic (Abumalloh et al., 2021; Durnali, 2020). Several aspects that were disturbed, namely the cultural aspect, the organizational wheels of social institutions, and the pattern of leadership in controlling power, all affected the COVID-19 pandemic. This research was conducted to answer the research question: how was social interaction during the COVID-19 period, grade IV elementary school in Pekanbaru. Based on this, this study aimed to analyze the pattern of social interaction during the COVID-19 period in grade IV elementary school.

\section{METHOD}

This study uses qualitative research to describe and analyze social interactions during student pandemics. The procedure in this research is to make initial observations, determine the topic of the problem, compile research instruments; data collection in the field, perform data analysis; make discussions and conclusions. Data collection techniques are in the form of questionnaires and; Interviews in this study 
were 90 students and three teachers. Researchers determine their data sources to obtain information about social interactions during the Covid-19 period. The instruments used are questionnaires and interviews. The questionnaire grid is presented in Table 1.

Table 1. Research Instruments

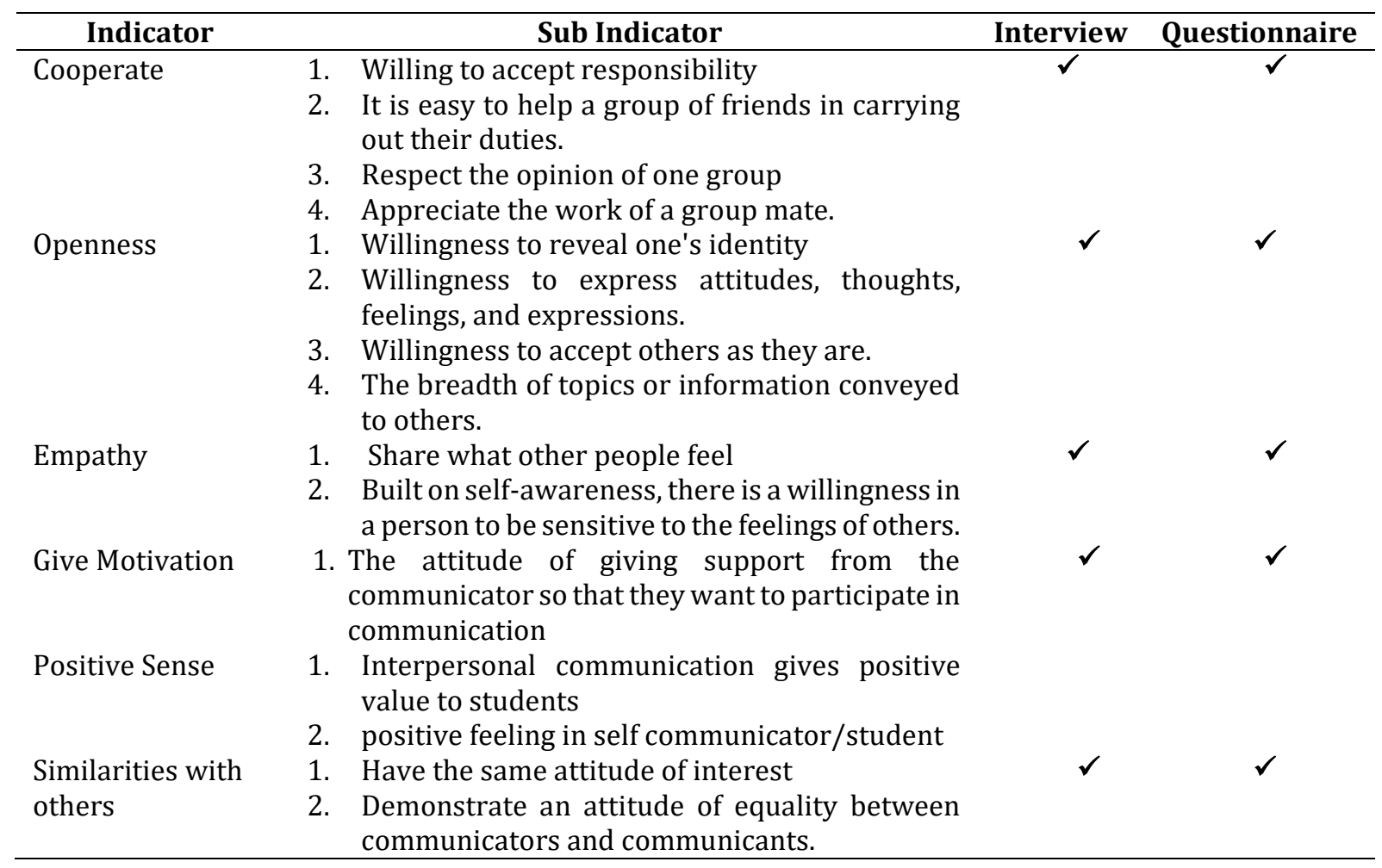

Analysis of interview data used descriptive qualitative. Analysis of research data using the Miles and Huberman model, namely, data reduction, data presentation, drawing conclusions. In testing the validity of the data, the researcher used triangulation. Triangulation is essentially a multi-method approach that researchers try when collecting checks and analyzing data. Percentage of respondent characteristics.

\section{RESULT AND DISCUSSION}

\section{Result}

Based on questionnaire survey data for 84 students on Student Social Interaction, it was found that during the Covid-19 Pandemic, student responses to social interaction towards online learning were positive (answer yes) or at a reasonable level, and only a few students answered no. Based on the table above, the results of the Social Interaction questionnaire for fourth-grade students at Pekanbaru Elementary School were 81.92, classified as "Good" because they were in the range of $80-89 \%$. So the student's social interaction in the pandemic has been carried out well. In this study, the solution given during Student Social Interaction, namely the teacher must give more attention to students so that students feel motivated in current social interactions. Moreover, parents should pay more attention and easily guide their students to interact with teachers and classmates. The principal has applied the shift method and uses health protocols. On the indicators of the student questionnaire working together, the average value is 82.43\%. They are classified as "good." It can be seen when students are given responsibility for learning, students fulfill their duties even though not all of them collect assignments, due to the factor of people who are busy at work, so they cannot supervise their children in making assignments. Parents must understand and understand the responsibility in educating children to know how the correct method is in educating children. Parents must be responsible for educating their children, but many parents forget and do not even have time to take care of their children's education. As a result, a lot is left behind in learning because parents do not supervise their children. Humans need help from other individuals or groups. Therefore we as humans carry out social interactions with the primary goal of survival.

In the openness student questionnaire indicator, the average value of $82.43 \%$ is classified as "good." Students during the pandemic have revealed their identities through videos made and sent via WhatsApp Groups. Students explain their identity through videos, but some students are not good at making 
introductory videos because parents do not understand technology. In addition, students need an internet quota in online learning today. Some students are still lacking in openness about learning. When delivering assignments, there are still students who are not good at opening youtube links and videos given by the teacher to students. In the use of online media, the teacher determines the communication media be used and adapted to the conditions of the education module, such as when giving the theoretical module using the WA Team. With the WA team, it is hoped that students will be able to complete the tasks given by the teacher together.

In the indicators of the student questionnaire giving motivation, an average value of $79.70 \%$ is classified as "good." Seen when learning, students mutually support each other in learning. It means that there is a feeling in students to motivate students who do not understand learning. Even students motivate by doing assignments together. From there, lazy friends will motivate students who help to be enthusiastic in learning even though online learning. The environment is one of the external aspects that can motivate a person to learn. Today's motivation is very much needed during the current pandemic. Motivation can increase enthusiasm in learning. Social interactions must change due to an outbreak of infectious disease, namely Covid-19 or Corona. Students need to learn today because the coronavirus has made face-to-face learning into online learning. Many students are less enthusiastic about participating in online lessons due to limitations. The effectiveness of learning becomes less learning. In this case, it is necessary to help parents supervise their children's online learning. Technological advances participate in social communication and learning when communicating online (Hanifah Salsabila et al., 2020). In this case, students need help from parents to be excited during the current pandemic. Parents need to teach their children how to use cell phones to facilitate online learning. At the same time, some parents have also experienced restrictions on smartphone-related facilities (Muhdi \& Nurkholis, 2021). For the problem of parents who do not understand the problem of smartphones, the teacher makes it easy for parents to take the tasks given by the teacher at school. Here the role of the teacher will provide direction and motivation in the current online learning process. During the covid-19 pandemic, cell phone functions are needed online even though they do not meet face-to-face during learning. Almost all students today have cell phones but are misused to play games. So the motivation in learning is significantly less. Many students are addicted to playing games so that learning is disrupted.

In the student questionnaire indicators, the average value of $81.56 \%$ is classified as "good." Seen when students can give positive values during learning where the positive value is developed from learning time where students help their friends in distress, for example, when students do not understand learning, students will help their friends who do not understand the learning. There is already a positive feeling to help students who do not understand learning. Positive thinking is the principal capital in instilling selfconfidence (Andinny, 2013). Many students lack confidence in their abilities, even harboring a talent. There needs to be confidence in students not to be ashamed to issue an idea. Many students lack confidence because they are afraid of being ridiculed by their friends, and there are still many students who are embarrassed to express their opinions about learning. Students who are not good at math are usually less confident. Self-confidence is an attitude of one's ability not to be disappointed in their actions, do what one wants, and take responsibility for their actions. In order to create self-confidence in students, it is necessary to have support from those around them.

On the indicators of student questionnaires similarity with others, the average value of $82.15 \%$ is classified as "good." There is a joint task with other people who appear when together with students in collecting assignments and doing homework. There is already a similarity to working with his friends close to his home. In students, it has been shown when students are friends with ABK students with autism. Students get along and do not look at students' status and social position. Gender equality means equality of conditions for men and women to get opportunities and rights as human beings (Rustina, 2017). During the current pandemic, there are no similarities with other people. However, it can be seen from the students who are friends even though there are children with special needs (children with special needs). Students make friends and play together, as seen from the shared task regardless of the student's social status. Similarities with other people are needed to know how similar interests and talents are. It is to strengthen the social interaction of students. As seen in Civics learning, namely Bhinneka Tunggal Ika, although they are different, they are still the same, so there is no difference between students. Also seen from Pkn learning, students must tolerate religion, ethnicity, and language. Bhinneka Tunggal Ika, as the shaper of the character and identity of the state, cannot be separated from the intervention of the state's founders. They understand that a diverse Indonesia requires binding elements and a shared identity (Salim, 2017). Students who apply Bhinneka Tunggal Ika will respect each other's differences. A sense of love for the homeland will jointly realize the ideals of the homeland. With an attitude of respect and willingness to work together, the learning objectives will be achieved. 


\section{Discussion}

In the Cooperating indicator, the teacher's group assignments at this time have not been carried out correctly. Due to the limitations of social distancing, online schools cannot be carried out because they are still in the red zone. Students have fulfilled their duties in carrying out assignments, although not all of them, and at the school, there are ABK (children with special needs) students where the teacher must be extra-large in paying attention to these ABK students. To achieve mutually beneficial outcomes, all parties must communicate well and reach conventions on shared goals (Kin et al., 2018; Lokay, 2015; Russo et al., 2021). In working together in a pandemic, students are less active, but in fulfilling their responsibilities in assignments, not all students collect because, in elementary school, there are children with special needs (children with special needs). Indicators of Openness, many students have revealed their identity through videos, students have expressed their politeness in learning, namely by answering greetings and praying together, and some students conclude learning and when the teacher asks "Are you happy with today's learning" students answer "Thrilled" is evidenced by a regular expression in the chat. Students now seem to accept other people as they are. In that class, there are students with special needs with autism, but students are still friends with these children with special needs, even working together in doing the assignments given by the teacher. The purpose of this social interaction is to improve children's social skills that will encourage and create children to improve thinking skills, behave based on the diversity of social realities (Anjasari et al., 2020; Istianti, 2018; Xiao, 2018). The teacher has given students a broad range of topics starting from assignments and when to submit assignments. Even the teacher provides information about the regulations that the principal informs. Information disclosure is also a tool for controlling and monitoring (Kristiyanto, 2016; Rimawati \& Wibowo, 2018). The openness will make it easier for students to communicate and inform. Social interaction in early childhood is necessary because children will be taught how to live in society.

In the Empathy indicator, students have participated in what other people feel. Empathy is a feeling of being in control of another person, participating in another person's emotional feelings, and being able to stand on that person's point of view. A sense of empathy can educate students to become individuals who care about others, help each other, participate and increase the sense of brotherhood between humans (Cahyani, 2019; Mardliyah et al., 2021; Silfiasari, 2018). Interaction barriers often found in people with autism are generally avoiding eye contact (Mardliyah et al., 2021; Utari et al., 2020; Widiastuti, 2014). Elementary school students during the pandemic did not appear to have empathy, but the thing that stood out during the pandemic could be seen from the students who made friends with their friends, even though there were children with special needs (ABK) children who were autistic. During the current pandemic, many students feel what other people feel. Students will imagine themselves in that position. However, during the current pandemic, there are still many students who are indifferent to their friends. They do not even care. They just focus on themselves. Students will only focus on the assignments given by the teacher. In learning, only some students help answer the teacher's questions if the students who are asked do not understand the task.

Indicator of Motivation: Teachers always motivate learning, starting from opening the lesson to closing. Motivation to students can be seen from the teacher giving the spirit of learning even though it is not facing to face. Even though only from WhatsApp Grub does the teacher not give up, some students do not do assignments and are indifferent, so the teacher will call the student and his parents to be given motivation and advice. Teachers must be able to increase student learning motivation by sharing learning challenges with students to be more active and passionate in the educational process (Hasfira \& Marelda, 2021; Low et al., 2019; Russo et al., 2021). Teachers make innovative learning so that learning is not monotonous (Kin et al., 2018; Olcum \& Titrek, 2015). In the positive sense indicator, the teacher has given a positive value as evidenced when learning that positive values are developed in everyday life. The positive feeling is seen from students' attitude in receiving learning, and the positive values that exist in students have been seen from students who say hello and pray and close the lesson. That way, the interaction between students and teachers has been seen during the pandemic. Online learning helps provide learning opportunities for everyone, thereby removing physical barriers that are a factor in learning in the classroom environment (Adi et al., 2021; Koh et al., 2010; Wang et al., 2020). Distance learning has the potential to increase learning independence, which can be seen in setting learning goals, learning strategies, time management, environment, seeking help, and self-assessment (Meriana et al., 2021; Mishra et al., 2020). Although many students feel uncomfortable with online learning, there is still a positive impact. Many students were previously only fixated on books and worksheets, but in online learning, students will get used to the learning provided by the teacher through innovative videos. Usually, students are still embarrassed to ask face-to-face questions, but students are not shy to ask questions in online learning. Even students dare to answer questions from the teacher if some of their friends cannot answer. 
On the indicators of similarity with others, the attitude of students' shared interests can be seen from students who answer greetings together, pray together, and do assignments together. Even friends cannot answer the teacher's questions, so the student helps answer the teacher's questions. The teacher also sees students who make friends and hang out with children with special needs. In every activity at school, elementary school children always establish good interactions with their friends, teachers, and other humans in the school environment. Many students have the same ideals, willingness to learn, and learning abilities. However, many students are indifferent in learning. Lack of willingness to learn can be seen by many students who play while doing the exercises. Lack of self-motivation to be enthusiastic in learning. Assessment of children related to children's learning activities is critical (Friantary \& Martina, 2018; Kamaruddin \& Haryanto, 2014). It is done to monitor the results of children's development achievements while participating in activities provided by the teacher (Dewi \& Lestari, 2020; Fadhilaturrahmi, 2017).

\section{CONCLUSION}

Social interaction of students during the current Covid-19 period is not running ideally compared to face-to-face. Social interaction is currently only with WhatsApp Grub, where students express their complaints about quota and network problems. There is also the problem of parents who are very busy with their work and do not have time to take care of their children in learning. Solving the problem of students' social interaction today can be done with a shift program or alternately. Although time is limited, it helps students interact even in small groups, individually with others and the teacher. Parents should supervise students in social media so that social interactions during this Covid-19 period run smoothly.

\section{REFERENCES}

Abumalloh, R. A., Asadi, S., Nilashi, M., Minaei-Bidgoli, B., Nayer, F. K., Samad, S., Mohd, S., \& Ibrahim, 0. (2021). The impact of coronavirus pandemic (COVID-19) on education: The role of virtual and remote laboratories in education. Technology in Society, 67(September 2020), 101728. https: //doi.org/10.1016/j.techsoc.2021.101728.

Adi, N. N. S., Oka, D. N., \& Wati, N. M. S. (2021). Dampak Positif dan Negatif Pembelajaran Jarak Jauh di Masa Pandemi COVID-19. Jurnal Imiah Pendidikan Dan Pembelajaran, 5(1), 43. https://doi.org/10.23887/jipp.v5i1.32803.

Ali, W. (2020). Online and Remote Learning in Higher Education Institutes: A Necessity in light of COVID-19 Pandemic. Higher Education Studies, 10(3), 16-25. https: //doi.org/10.5539/hes.v10n3p16.

Andinny, Y. (2013). Pengaruh Konsep Diri Dan Berpikir Positif Terhadap Prestasi Belajar. Formatif : Jurnal Ilmiah Pendidikan MIPA, 3(2), 126-135. https://doi.org/10.30998/formatif.v3i2.119.

Anjasari, E. A., Srinandi, I. G. A. M., \& Nilakumawati, D. P. E. (2020). Hubungan Kecanduan Bermain Game Online Terhadap Interaksi Sosial Pada Remaja (The Relationship between Online Game Addiction and Social Interaction in Adolescents). E-Jurnal Matematika, 9(Agustus), 177-181. https://doi.org/10.24843/MTK.2020.v09.i03.p296.

Astuti, I. Y. (2021). Tantangan Guru dan Orang Tua dalam Kegiatan Belajar Dari Rumah Anak Usia Dini pada Masa. Jurnal Obsesi: Journal of Early Childhood Education, 5(2), 1454-1463. https://doi.org/10.31004/obsesi.v5i2.808.

Batubara, H. H., \& Batubara, D. S. (2020). Penggunaan Video Tutorial untuk Mendukung Pembelajaran Daring di Masa Pandemi Virus Corona. Jurnal Madrasah Ibtidaiyah, 5(2), 78-84. https://doi.org/10. 31602 /muallimuna.v5i2.2950.

Cahyani, N. (2019). Psikodrama untuk Meningkatkan Empati Siswa di Sekolah Inklusif. Inklusi, 6(2), 259. https://doi.org/10.14421/ijds.060204.

Damanik, M. R., \& Setiawan, D. (2016). Pengembangan Penilaian Autentik Berbasis Karakter Pada Ranah Keterampilan Di Fakultas Ilmu Sosial Universitas Negeri Medan. Jurnal Pendidikan Ilmu-Ilmu Sosial, 8(2). https://doi.org/10.24114/jupiis.v8i2.5150.

Dewantara, J. A., \& Nurgiansah, T. H. (2020). Efektivitas Pembelajaran Daring di Masa Pandemi COVID 19 Bagi Mahasiswa Universitas PGRI Yogyakarta. Jurnal Basicedu, 5(1), 367-375. https: //doi.org/10.31004/basicedu.v5i1.669.

Dewi, M. S. A., \& Lestari, N. A. P. (2020). E-Modul Interaktif Berbasis Proyek terhadap Hasil Belajar Siswa. Jurnal Imiah Pendidikan Dan Pembelajaran, 4(3), 433-441. https://doi.org/10.23887/jipp.v4i3.28035.

Dewi, W. A. F. (2020). Dampak Covid-19 Terhadap Implementasi Pembelajaran Daring Di Sekolah Dasar. Jurnal Ilmu Pendidikan, 2(1). https: //doi.org/10.31004/edukatif.vi1.89. 
Durnali, M. (2020). The Effect of Self-Directed Learning on the Relationship Between Self-Leadership and Online Learning among University Students in Turkey. Tuning Journal for Higher Education, 8(1), 129-165. https://doi.org/http://dx.doi.org/10.18543/tjhe-8(1)-2020pp129-165.

Fadhilaturrahmi. (2017). Peningkatan Hasil Belajar Siswa pada Materi Jaring-Jaring Balok dan Kubus dengan Pendekatan Contextual Teaching and Learning (CTL) Siswa Kelas IV SDN 05 Air Tawar Barat. Jurnal Basicedu, 1(1), 1-9. https://doi.org/10.31004/basicedu.v1i1.9.

Firman, \& Rahman, S. R. (2020). Pembelajaran Online di Tengah Pandemi Covid-19. Indonesian Journal of Educational Science (IJES), 2(2), 81-89. https://doi.org/10.31605/ijes.v2i2.659.

Friantary, H., \& Martina, F. (2018). Evaluasi Implementasi Penilaian Hasil Belajar Berdasarkan Kurikulum 2013 oleh Guru Bahasa Inggris dan Bahasa Indonesia di MTS Ja-Alhaq Kota Bengkulu. Silampari Bisa: Jurnal Penelitian Pendidikan Bahasa Indonesia, Daerah, Dan Asing, 1(2), 76-95. https://doi.org/10.31540/silamparibisa.v1i2.202.

Handayani, P. (2017). Upaya Peningkatan Keterampilan Sosial Siswa Melalui Permainan Tradisional Congklak Pada Mata Pelajaran IPS. Premiere Educandum: Jurnal Pendidikan Dasar Dan Pembelajaran, 7(01), 39. https://doi.org/10.25273/pe.v7i01.1245.

Hanifah Salsabila, U., Irna Sari, L., Haibati Lathif, K., Puji Lestari, A., \& Ayuning, A. (2020). Peran Teknologi Dalam Pembelajaran Di Masa Pandemi Covid-19. Al-Mutharahah:Jurnal Penelitian Dan Kajian Sosial Keagamaan, 17(2), 188-198. https://doi.org/10.46781/al-mutharahah.v17i2.138.

Hasfira, H., \& Marelda, M. (2021). Peran Guru Dalam memotivasi Siswa Pada Masa Pandemi. Jurnal Pendidikan Dan Konseling (JPDK), 3(1), 80-84. https://doi.org/10.31004/jpdk.v3i1.1430.

Hasti, R., \& Nurfarhanah. (2013). Hubungan Antara Interaksi Sosial Teman Sebaya Dengan Kemandirian Perilaku Remaja ( Studi Korelasional Terhadap Smp N 1 Padang Panjang ). Konselor, 2(1). https://doi.org/10.24036/02013211267-0-00.

Herfinaly, R., \& Aryani, L. (2013). Interaksi Sosial Remaja Yang Bersekolah di Homeschooling Dengan Menggunakan Metode Distance Learning. Jurnal Psikologi, 9(1). https://doi.org/10.24014/jp.v9i1.147.

Istianti, T. (2018). Pengembangan Keterampilan Sosial Untuk Membentuk Prilaku Sosial Anak Usia Dini. Cakrawala Dini: Jurnal Pendidikan Anak Usia Dini, 6(1), 32-38. https://doi.org/10.17509/cd.v6i1.10515.

Kamaruddin, \& Haryanto. (2014). Pengembangan Sistem Penilaian Hasil Belajar Mata Pelajaran Menganalisis Rangkaian Listrik Berbasis Computerized Adaptive Testing. Jurnal Pendidikan Vokasi, 4(1). https://doi.org/10.21831/jpv.v4i1.2533.

Kin, T. M., Abdull Kareem, O., Nordin, M. S., \& Wai Bing, K. (2018). Principal change leadership competencies and teacher attitudes toward change: the mediating effects of teacher change beliefs. International Journal of Leadership in Education, 21(4), 427-446. https://doi.org/10.1080/13603124.2016.1272719.

Koh, J. H. L., Herring, S. C., \& Hew, K. F. (2010). Project-based learning and student knowledge construction during asynchronous online discussion. Internet and Higher Education, 13(4), 284-291. https://doi.org/10.1016/j.iheduc.2010.09.003.

Kristiyanto, E. N. (2016). Urgensi Keterbukaan Informasi dalam Penyelenggaraan Pelayanan Publik. Jurnal Penelitian Hukum De Jure, 16(2), 231-244. https://doi.org/10.30641/dejure.2016.V16.231-244.

Lokay, A. C. (2015). Pengaruh Komunikasi, Kerjasama Kelompok, dan Kreativitas terhadap Kinerja Karyawan pada Hotel Aryaduta Manado. Jurnal EMBA, 3(3), 981-991. https://doi.org/10.35794/emba.3.3.2015.9773.

Low, E. L., Ng, P. T., Hui, C., \& Cai, L. (2019). How do teacher affective and cognitive self-concepts predict their willingness to teach challenging students? Australian Journal of Teacher Education, 44(10), 18-34. https://doi.org/10.14221/ajte.2019v44n10.2.

Mardliyah, S., Yulianingsih, W., \& Putri, L. S. R. (2021). Sekolah Keluarga: Menciptakan Lingkungan Sosial untuk Membangun Empati dan Kreativitas Anak Usia Dini. Jurnal Obsesi : Jurnal Pendidikan Anak Usia Dini, 5(1). https://doi.org/10.31004/obsesi.v5i1.665.

Maulana, H. A. (2021). Psychological Impact of Online Learning during the COVID-19 Pandemic: A Case Study on Vocational Higher Education. Indonesian Journal of Learning Education and Counseling, 3(2), 130-139. https://doi.org/10.31960/ijolec.v3i2.833.

Maulana, H. A., \& Hamidi, M. (2020). Persepsi Mahasiswa terhadap Pembelajaran Daring pada Mata Kuliah Praktik di Pendidikan Vokasi. Equilibrium: Jurnal Pendidikan, 8(2), 224-231. https://doi.org/10.26618/equilibrium.v8i2.3443.

Mayer, R. E., \& Wittrock, M. C. (2006). Problem soving. Handbook of Eductional Psychology, 1(1), 287-303.

Meriana, T., Angelius Domes, A., -, Y., \& Sihotang, H. (2021). The Impact of the Covid-19 Pandemic on Students Behaviour During Online Learning at Pelangi Kasih Elementary School in Jakarta. 
Advances in Social Sciences Research Journal, 8(4), 594-604. https://doi.org/10.14738/assrj.84.10112.

Mishra, L., Gupta, T., \& Shree, A. (2020). Online teaching-learning in higher education during lockdown period of COVID-19 pandemic. International Journal of Educational Research Open, 1, 100012. https://doi.org/10.1016/j.ijedro.2020.100012.

Muhdi, \& Nurkholis. (2021). Keefektivan Kebijakan E-Learning berbasis Sosial Media pada PAUD di Masa Pandemi Covid-19 Abstrak. Jurnal Obsesi : Jurnal Pendidikan Anak Usia Dini, 5(1), 212-228. https://doi.org/10.31004/obsesi.v5i1.535.

Olcum, D., \& Titrek, O. (2015). The effect of school administrators' decision-making styles on teacher job satisfaction. Procedia - Socialand Behavioral Sciences, 197, 1936-1946. https://doi.org/10.1016/j.sbspro.2015. 07.575.

Pratama, R. E., \& Mulyati, S. (2020). Pembelajaran Daring dan Luring pada Masa Pandemi Covid-19. Gagasan Pendidikan Indonesia, 1(2), 49. https://doi.org/10.30870/gpi.v1i2.9405.

Prawiyogi, A. G., Purwanugraha, A., Fakhry, G., \& Firmansyah, M. (2020). Efektifitas Pembelajaran Jarak Jauh Terhadap Pembelajaran Peserta didik di SDIT Purwakarta. JPD: Jurnal Pendidikan Dasar, 11(1). https://doi.org/10.21009/10.21009/JPD.081.

Putri, A. P., Rahhayu, R. S., Suswandari, M., \& Ningsih, P. A. R. (2021). Strategi Pembelajaran Melalui Daring Dan Luring Selama Pandemi Covid-19 Di Sd Negeri Sugihan 03 Bendosari. Prima Magistra: Jurnal Ilmiah Kependidikan, 2(1), 1-8. https: //doi.org/10.37478/jpm.v2i1.728.

Putri, V. D. (2020). Layanan Bimbingan dan Konseling Daring Selama Masa Pandemi COVID-19. Jurnal Bimbingan Konseling Pendidikan Islam, 1(2), 7-16. https://doi.org/10.47453/coution.v1i2.95.

Rahma, N. A., \& Pujiastuti, H. (2021). Efektivitas Pembelajaran Daring Matematika Pada Masa Pandemi Covid-19 Di Kota Cilegon [the Effectiveness of Mathematics Online Learning During the Covid-19 Pandemic in Cilegon City]. JOHME: Journal of Holistic Mathematics Education, 5(1), 1. https: //doi.org/10.19166/johme.v5i1.3811.

Riansyah, H., \& Wulandari, W. (2017). Layanan bimbingan kelompok dalam meningkatkan interaksi sosial siswa. Teraputik: Jurnal Bimbingan Dan Konseling, 1(1). https://doi.org/10.26539/1110.

Ridha, M., Firman, \& Desyandri. (2021). Efektifitas Penggunaan Media Video pada Pembelajaran Tematik Terpadu di Sekolah Dasar Saat Pandemi Covid-19. Jurnal Pendidikan Tambusai, 5(1), 154-162. https://doi.org/10.31004/jptam.v5i1.925.

Rimawati, E., \& Wibowo, A. (2018). Pengaruh Persepsi Guru Sekolah Dasar Terhadap Minat Menggunakan Internet Sebagai Sumber Belajar. Jurnal Sains Dan Informatika, 4(2). https://doi.org/10.34128/jsi.v4i2.134.

Russo, J., Bobis, J., Downton, A., Livy, S., \& Sullivan, P. (2021). Primary teacher attitudes towards productive struggle in mathematics in remote learning versus classroom-based settings. Education Sciences, 11(2), 1-13. https://doi.org/10.3390/educsci11020035.

Rustina, R. (2017). Implementasi Kesetaraan Dan Keadilan Gender Dalam Keluarga. Musawa: Journal for Gender Studies, 9(2), 283-308. https://doi.org/10.24239/msw.v9i2.253.

Sabran, \& Sabara, E. (2019). Keefektifan Google Classroom sebagai media pembelajaran. Prosiding Seminar Nasional Lembaga Penelitian Universitas Negeri Makasar, 122-125.

Salim, M. (2017). Bhinneka Tunggal Ika Sebagai Perwujudan Ikatan Adat-Adat Masyarakat Adat Nusantara. Al Daulah: Jurnal Hukum Pidana Dan Ketatanegaraan, 6(1), 65-74. https://doi.org/10.24252/ad.v6i1.4866.

Sari, I. P. (2017). Implementasi Pembelajaran Berbasis E-Learning Menggunakan Claroline. Research and Development Journal of Education, 4(1), 75-87. https://doi.org/10.30998/rdje.v4i1.2070.

Sari, R. P., Tusyantari, N. B., \& Suswandari, M. (2021). Dampak Pembelajaran Daring Bagi Siswa Sekolah Dasar Selama Covid-19. Prima Magistra: Jurnal Ilmiah Kependidikan, 2(1), 9-15. https://doi.org/10.37478/jpm.v2i1.732.

Silfiasari, S. P. (2018). Empati Dan Pemaafan Dalam Hubungan Pertemanan Siswa Regular Kepada Siswa Berkebutuhan Khusus (Abk) Di Sekolah Inklusif. Journal of Chemical Information and Modeling, 53(9), 1689-1699. https://doi.org/10.22219/jipt.v5i1.3886.

Tamboto, H., Tambingon, H. N., Lengkong, J. S. ., \& Rotty, V. N. J. (2021). The Involvement of Students' Parents in Organizing the Learning from Home at Elementary Schools in Tomohon City. Asia Pacific Journal of Management and Education, 4(1), 35-51. https://doi.org/10.32535/apjme.v4i1.1044.

Utari, L., Kurniawan, \& Fathurrochman, I. (2020). Peran Guru Pendidikan Agama Islam dalam Membina Akhlak Peserta Didik Autis. JOEAI (Journal of Education and Instruction), 3(1), 75-89. https://doi.org/10.31539/joeai.v3i1.1304. 
Vera, N. (2020). Strategi Komunikasi Dosen Dan Mahasiswa Dalam Meningkatkan Kualitas Pembelajaran Daring Selama Pandemic Covid-19. Avant Garde, 8(2), 165. https://doi.org/10.36080/ag.v8i2.1134.

Wakhid, A., Andriani, N. S., \& Saparwati, M. (2019). Kemampuan Interaksi Sosial Siswa Usia 10-12 Tahun Diungaran. Jurnal Keperawatan Jiwa, 5(2), 87. https://doi.org/10.26714/jkj.5.2.2017.87-90.

Wang, J., Antonenko, P., \& Dawson, K. (2020). Does Visual Attention To The Instructor in Online Video Affect Learning and Learner Perceptions? An Eye-Tracking Analysis. Computers and Education, 146, 103779. https://doi.org/10.1016/j.compedu.2019.103779.

Widiastuti, D. (2014). Perilaku Anak Berkebutuhan Khusus Gangguan Autisme Di Slb Negeri Semarang Tahun 2014. BELIA: Early Childhood Education Papers, 3(2), 72-78. https://doi.org/10.15294/belia.v3i2.3754.

Xiao, A. (2018). Konsep Interaksi Sosial Dalam Komunikasi, Teknologi, Masyarakat. Jurnal Komunika : Jurnal Komunikasi, Media Dan Informatika, 7(2). https://doi.org/10.31504/komunika.v7i2.1486.

Yulia, H. (2020). Online Learning to Prevent the Spread of Pandemic Corona Virus in Indonesia. English Teaching Journal, 11, 48-56. https://doi.org/10.26877/eternal.v11i1.6068. 